\title{
Prof. dr hab. Teresa Zielińska (10 V 1929 - 15 II 2010)
}

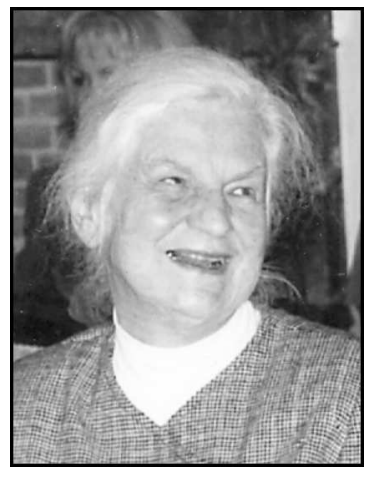

Archiwistyka i historia - te wzajemnie uzupełniające się dziedziny wiedzy były treścią życia zawodowego i naukowego prof. dr hab. Teresy Zielińskiej. Starała się poświęcać im swój czas i uwagę w równym stopniu. Lecz obserwując jej pracę i dorobek, można odnieść nieodparte wrażenie, że to archiwistyka była bliższa Jej sercu. Świadczy o tym 58 lat przepracowanych przez Nią w pierwszym - i jedynym! - miejscu pracy, Archiwum Głównym Akt Dawnych w Warszawie. Co więcej, uzyskując kolejne stopnie naukowe na gruncie historii, ani przez moment nie zrezygnowała z pracy w AGAD, ani przez chwilę nie zawieszała swoich działań nad porządkowaniem zespołów archiwalnych, tworzeniem pomocy archiwalnych, nawet gdy formalnie była już na emeryturze.

Z AGAD związała się w 1951 r., jeszcze podczas odbywania studiów w Instytucie Historycznym Uniwersytetu Warszawskiego. Po ukończeniu studiów w roku następnym praca w tej instytucji nabrała trwałego charakteru. Od początku była zatrudniona w Oddziale III, w którym gromadzone są akta rodzin i osób prywatnych oraz ich posiadłości. Praca w tym oddziale wymaga wszechstronnej, wciąż pogłębianej wiedzy i nieustannego doskonalenia umiejętności warsztatowych. Teresa Zielińska uporządkowała oraz była autorką bądź współautorką inwentarzy do dziesięciu zespołów archiwalnych. Są to na ogół obszerne, niezwykle bogate w materiały archiwalne m.in. takie zespoły, jak: Archiwum Zamoyskich, Archiwum Radziwiłłów dz. X i XI, Zbiór Czołowskiego, skatalogowała Teki Glinki. Bodaj największym Jej dziełem archiwalnym było porządkowanie i opracowywanie Archiwum Roskiego: Akta rodzinno-majątkowe. Publika. Militaria. Jeszcze latem 2009 r., pomimo że była już poważnie chora, żyła nadzieją, że uda się Jej dokończyć tę pracę. Niestety, nie było Jej to dane. A do końca zabrakło już naprawdę niewiele...

Równolegle z pracami archiwalnymi postępowały publikacje naukowe. Pierwsze artykuły dotyczyły problematyki archiwaliów prywatnych. Ale pojawiły 
się też teksty, w których prezentowała informacje pochodzące z własnych znalezisk źródłowych odkrytych podczas porządkowania archiwaliów. Szczególnie ceniła sobie odnalezienie w Archiwum Roskim kwitu dokumentującego sprzedaż przez Jana Sebastiana Bacha fortepianu Janowi Klemensowi Branickiemu do Białegostoku. Drobny przyczynek posłużył jako inspiracja do napisania dwóch świetnych tekstów dotykających problematyki a) mecenatu Branickiego; b) recepcji fortepianu w Europie w XVIII w.; wreszcie c) ustaleń „Bachologicznych” - podpis Jana Sebastiana był ostatnim zachowanym jego autografem, zaś treść pokwitowania została napisana przez syna, Jana Krzysztofa Fryderyka Bacha (Osiemnastowieczna transakcja zakupu fortepianu, „KHKM”, t. 15: 1967, nr 3, s. 523-526), (Nieznany autograf Jana Sebastiana Bacha, „Muzyka”, t. 12: 1967, nr 4, s. 67-70).

Od lat 70. zaczyna wzrastać liczba publikacji poświęconych problematyce historycznej. Wówczas też przygotowuje rozprawę doktorską pod kierunkiem prof. Janiny Leskiewiczowej, pt. Magnateria polska epoki saskiej. Funkcje urzędów i królewszczyzn w procesie przeobrażeń warstwy społecznej. Praca zostaje ogłoszona drukiem w 1977 roku. Zdobywa uznanie środowiska historyków zarówno ze względu na problematykę, nowatorstwo metodologiczne, jak też - czemu się trudno dziwić - znakomity warsztat. Sekretarz Naukowy PAN uhonorował ją nagrodą. Doczekała się pięciu recenzji krajowych i trzech zagranicznych (na łamach „Revue Historique”, „American Historical Review” i „Zeitschrift für Ostforschung"). Problematyce szlachecko-magnacko-arystokratycznej pozostanie do końca wierna w swych badaniach. Dekadę później w oparciu o dorobek naukowy ukoronowany książką: Szlacheccy właściciele nieruchomości w miastach XVIII stulecia (Warszawa 1987), Teresa Zielińska uzyskuje habilitację. I w tym wypadku publikacja książki została doceniona przez badaczy. Świadczy o tym pięć recenzji zamieszczonych na łamach fachowych periodyków. Dziesięcioletni rytm pracy naukowej zostaje utrzymany i w 1997 r. ukazuje się Poczet polskich rodów arystokratycznych. Porozumienie Wydawców Książki Historycznej nagradza publikację nagrodą „Klio” pierwszego stopnia w kategorii autorskiej. Dzieło to stanowi kompendium wiedzy o czołowych rodach arystokratycznych. Problemy genealogiczne w mistrzowski sposób włączone zostały w problematykę polityczną, społeczną, gospodarczą.

Bibliografia prac prof. Teresy Zielińskiej liczy sobie 110 pozycji. Ogrom i jakość dorobku robią wrażenie, tym bardziej, że publikacje powstawały „po godzinach”, po odbyciu ośmiogodzinnej pracy archiwalnej. Kilka z nich ukaże się drukiem już jako opera posthuma...

Archiwistka, uczona, przede wszystkim jednak była wspaniałym człowiekiem. W czasach, gdy jeszcze wnętrza AGAD nie chronili strażnicy i kody dostępu, do pokoju, w którym pracowała Pani Teresa (nikt ze znajomych i prawie nikt z nieznajomych nie zwracał się do niej inaczej, pomimo kolejnych awansów w hierarchii naukowej), ciągnęły pielgrzymki: po poradę archiwalną i historyczną 
albo w celach towarzyskich. Cierpliwie, przy kawie lub herbacie, znajdowała czas na rozmowę. Można tu było spotkać i poznać historyków z całej Polski, jak też z zagranicy. Broniła się ze wszystkich sił przed obowiązkami administracyjnymi i jakimikolwiek stanowiskami służbowymi. Jednakże poprzez swoją postawę była niewątpliwym autorytetem i naukowym, i moralnym dla współpracowników. Teoretycznie nie pozostawiła po sobie uczniów, „teoretycznie”, bo my wszyscy korzystający z Jej rad, biorący udział w dyskusjach z Nią, czujemy się poniekąd Jej uczniami.

Nic tak dobrze nie charakteryzuje postawy Pani Teresy, jak historia Jej rocznej „banicji” z AGAD. Otóż, gdy w 1985 r. w wielu środowiskach podpisywane były protesty przeciwko usunięciu z pracy w IH PAN prof. Bronisława Geremka, pośród licznych sygnatariuszy protestów znalazło się oczywiście nazwisko Teresy Zielińskiej. Ówczesne władze archiwalne - nie wiedzieć, z jakiego powodu - uznały, że była Ona inspiratorką protestu na terenie AGAD. Zadecydowały, że „za karę” zostanie upokorzona rocznym przeniesieniem do Archiwum Państwowego m. st. Warszawy. Dla osoby tak związanej z macierzystą instytucją jak Pani Teresa, była to naprawdę kara dotkliwa. Tymczasem Ona nie dała po sobie nic poznać, nie stroiła się w szaty „męczennicy reżimu”, do całej sprawy odniosła się z charakterystycznym dla siebie dystansem i w swoim nowym miejscu pracy... po prostu sporządziła indeks korespondencji do Zbioru Borotyńskich.

Pośród przyjaciół i znajomych Pani Teresy krążyła żartobliwa, acz niepozbawiona podstaw opinia, że za badania historyczne wzięła się Ona po odchowaniu trójki dzieci. Faktem jest, ze rodzina bardzo wiele dla Niej znaczyła. W czasach, gdy nie śniło się jeszcze nikomu o programach komputerowych, diagramy i wykresy do książki o magnaterii epoki saskiej sporządził Jej mąż, Andrzej Zieliński, znany i ceniony architekt.

Bardzo wiele znaczyła dla Niej wiara, pozwolimy sobie na wyrażenie naszego poglądu, że przeżywana zgodnie z zasadą „fides quaerens intellectum”, wiara poszukująca zrozumienia. Nie była religijna na pokaz. Nie obnosiła się z uczynkami miłosierdzia. O tym, że uczestniczyła w prowadzeniu parafialnej kuchni dla ubogich dowiedzieliśmy się z mów wygłaszanych nad Jej grobem na Powązkach.

Zbanalizowanym, a nawet irytującym jest stwierdzenie, że nie ma ludzi niezastąpionych. Irytującym, gdy żegnamy kogoś takiego formatu, jak prof. Teresa Zielińska. Ale ponieważ pompatyczność i ponuractwo było Jej samej obce, więc z wdzięcznością korzystajmy z Jej dorobku archiwalnego i historycznego, zaś ci, którzy mieli zaszczyt i przyjemność znać Panią Teresę osobiście, niech z radością wspominają spędzone $\mathrm{z}$ Nią chwile na rozmowach i dyskusjach zawsze nacechowanych życzliwością i ciepłym, dyskretnym humorem.

Ewa Dubas-Urwanowicz, Jerzy Urwanowicz Białystok 